УДК 337.35

DOI:

Галина Кузан, кандидат філологічних наук, доиент кафедри іноземних мов Національного університету "Львівська політехніка"

\title{
ПРОФЕСІЙНА ПІДГОТОВКА ФАХІВЦІВ СОЩІОНОМІЧНИХПРОФЕСІЙ У ВИМІРІ СУЧАСНИХ ВИМОГ І РЕАЛІЙ
}

У статті окреслено специфічні особливості сочіономічних професій, розглянуто окремі аспекти професійної підготовки у вищій школі майбутніх фахівців соиіономічної сфери; акцентовано на актуальності компетентнісної освіти та впровадженні інтерактивної моделі навчання студентів з метою забезпечення якості їх підготовки до майбутньої професійної діяльності на рівні міжнародних вимог, щчо передбачає формування в них здатності добре орієнтуватися в сучасних реаліях й адекватно реагувати на них, знаходити оптимальні шляхи попередження та подолання виникаючих проблем, конкурентоспроможності як на вітчизняному, так і світовому ринку праці на основі осучаснення змісту освіти з чіткою орієнтачією на майбутнє, застосування інтерактивних методів навчання, щзо сприяють розвитку метакомпетентності майбутніх фахівців, здатності до рефлексії та відповідальності за прийняті рішення, а також створення умов, які б спонукали сьогоднішніх студентів до саморозвитку, самовдосконалення протягом усього трудового життя.

Ключові слова: професійна діяльність; професійна підготовка; сочіономічні професії; компетентнісна освіта; інтерактивні методи навчання.

Jim. 9.

Halyna Kuzan, Ph.D.(Philology), Associate Professor of the Foreign Languages Department National University "Lviv Polytechnic"

\section{PROFESSIONAL TRAINING OF SOCIONOMY SPECIALISTS IN THE DIMENTIONS OF CURRENT DEMANDS AND REALITIES}

The article concerns specific features of socionomy professions, deals with particular aspects of professional training in higher educational institutions of future specialists of socionomy profession, emphasizes the actuality of competence education and application/introducing of interactive model/pattern of teaching students with the purpose of providing quality of their training for their future activity on the international level requirements, that foretell the formation of their skills to orient themselves react accordingly to the current situation; find out the optimal ways for predicting and solving the possible problems; competitiveness concerning domestic and world job market on the basis of update educational content with the accurate orientation for future; applying of interactive methods of learning, cause the development of meta competitevenes of future specialists, abilities to reflexion and responsibilities for making decisions, as well as creating conditions, that will induce today's students to selfdevelopment and self-improvement during all their work life.

Keywords: professional activity; professional training; socionomy profession; competence education; interactive methods of education.

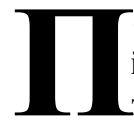
остановка проблеми та іїі зв'язок із важливими практичними завданнями. Соціально-економічні та соціально-політичні перетворення в Україні у зв'язку з набуттям незалежності, входження України в європейський освітній простір висуває низку вимог до професійної підготовки майбутніх фахівців соціономічних професій, діяльність яких відбувається у системі людина - людина, вимагає докорінної перебудови вітчизняної системи освіти як важливого джерела інтелектуального потенціалу країни, осучасненння освітньої практики, її переорієнтації з процесу на результат, зумовлює необхідність удосконалення змісту, форм і методів професійної підготовки фахівців у вищій школі на рівні міжнародних вимог, здатних добре орієнтуватися у сучасних реаліях й адекватно реагувати на них, знаходити оптимальні шляхи попередження і подолання виникаючих проблем, конкурентоспроможних як на вітчизняному, так і світовому ринку праці, готових до самоосвіти, самоудосконалення, щоби гідно своїми професійними діями відповідати на виклики сьогодення. Це, своєю чергою, зумовлює набуття майбутніми фахівцями не тільки базових знань, сформованих умінь і навичок, практичного досвіду й норм поведінки, а насамперед фахових компетенцій.

Аналіз останніх досліджень і публікацій Різні аспекти проблеми підготовки майбутніх фахівців у вищій школі до ефективної професійної діяльності стали об'єктом пильної уваги багатьох 


\section{ПРОФЕСІЙНАПЦДГОТОВКАФАХІВЦІВ СОЦІОНОМІЧНИХ ПРОФЕСІЙ У ВИМІРІ СУЧАСНИХ ВИМОГ І РЕАЛІЙ}

науковців і практиків. Так, зокрема, концепції розвитку освіти та організації навчального процесу у закладах вищої освіти розглянуто у наукових розвідках В. Андрущенко, С. Архангельського, В. Беспалько, С. Гончаренко, І. Зязюна, М. Свтуха, Р. Кавериної, В. Креміня, В. Лутай, І. Тихонова та ін.; питання гуманізації професійної освіти розглядалися такими науковцями, як Г. Балл, І. Бех, О. Бодальов, С. Бондаревська, С. Гончаренко, М. Євтух, І. Зязюн, В. Кудін, В. Онищук, А. Сущенко, Т. Сущенко, Н. Тализіна, Г. Щукіна та ін.; наукові уявлення про особистість професіонала і закономірності його становлення представлені у працях В. Болучевської, В. Бодрова, Є. Климова, Б. Ломова, А. Маркової, В. Шадрікова та ін.; питання формування особистісних та професійних якостей у процесі підготовки фахівців соціономічних спеціальностей досліджувались науковцями В. Болучевською, Т. Васильєвою, Б. Ломовим, А. Марковою, І. Нікішиною, О. Проніною, В. Шадріковим та ін; особливості діяльності суб' єктів соціономічних професій та розширення спектру їх професійних ролей в сучасних умовах вивчали В. Зазикін, Б. Косов, Р. Кричевський, К. Левін, Н.В. Ревенко, Ф. Фідлер та інші. Значна увага науковою аудиторією приділялася дослідженню удосконалення змісту та педагогічного інструментарію формування професійналізму фахівця у вищій школі, вивченню конкретних педагогічних умов професійної підготовки фахівців соціономічних професій, зокрема й у залежності від сфери їх діяльності (С. Архипова, О. Безпалько, О. Біла, І. Богданова, В. Бочарова, Л. Буркова, Н. Гордієнко, С. Гвоздій, А. Капська, О. Карпенко, Л. Коваль, І. Ковчина, В. Корнещук, М. Лукашевич, І. Мигович, В. Поліщук, В. Полтавець, В.Сластьонін,С. Толстоухова, С. Харченко та ін.). У той же час, аналіз представленого в наукових публікаціях педагогічного інструментарію, способів організації навчання студентів свідчить про те, що проблема підготовки майбутніх фахівців соціономічної сфери не втрачає актуальності й вимагає подальшого вивчення $з$ урахуванням як нових вимог до організації навчання у вищій школі, так і реалій, у яких свою професійну діяльність будуть здійснювати ці фахівці.

Метою даної статті $\epsilon$ спроба проаналізувати деякі особливості формування у вищій школі професійної компетентності майбутніх фахівців соціономічної сфери у світлі сучасних вимог і реалій.

Виклад основного матеріалу. Вибір нами у якості об'єкту дослідження особливостей професійної підготовки фахівців соціономічної сфери зумовлено насамперед специфікою даної професійної діяльності, визначальною ознакою якої виступає суб'єкт-суб'єктна взаємодія та допомагаюча поведінка фахівця.

Професії соціономічного типу пов'язані 3 навчанням та вихованням (учитель, вихователь, гувернер тощо; наданням соціальної, соціальнопедагогічної чи психологічної допомоги (соціальний працівник, соціальний педагог, психолог); з медичним обслуговуванням (лікар, медсестра); з наданням правової допомоги (юрист) тощо.

Надзвичайно складні соціальні умови українського сьогодення характеризуються особливою гостротою, ламкою усталених стереотипів, що відбивається практично на всіх сферах життєдіяльності людини, зумовлюють розширення соціального попиту на фахівців соціономічних спеціальностей, спонукають до досліджень удосконалення їх професійної підготовки у вищій школі, спрямованої на формування компетентного фахівця, об'єктом праці якого є людина 3 iii різноманітними проблемами і труднощами, особливостями реакції на них.

Окреслюючи специфічні особливості соціономічних професій, науковці наголошують на одній $з$ основних і водночас найбільш важливій функції працівника цієї сфери, що полягає в оцінці стану соціальних об'єктів, управлінні людьми, навчанні, вихованні, інформаційному, соціальнопобутовому, медичному обслуговуванні людей [6, 68], акцентують увагу на засобах їх діяльності, відзначаючи, що головним засобом виступає особистість самого фахівця, з притаманними йому особистісними якостями, здібностями та здатностями, досвідом роботи [2; 3]. Інша ж характерна особливість засобів діяльності фахівців цієї сфери полягає в тому, що операційна сторона їх праці представлена як самому фахівцеві, так і оточуючим досить обмежено та однобічно (оскільки саме на цих працівниках лежить обов'язок надати допомогу, організувати, розв'язати проблеми й т.ін.), що, своєю чергою, висуває особливі вимоги до індивідуально-творчого підходу до надання допомоги людині [7]. Так, наприклад, соціальний працівник, працюючи 3 клієнтом, повинен ураховувати причини виникнення проблеми у клієнта й ступінь їі загрозливості для нього та оточуючих, рівень усвідомлення чи неусвідомлення проблеми з боку клієнта, рівень його готовності чи неготовності до її вирішення; особливості психотипу клієнта, що значною мірою зумовлює тактику насамперед комунікативної 


\section{ПРОФЕСЙНАПЦГОТОВКАФАХІВЦІВСОЦЮНОМІЧНИХ ПРОФЕСІЙ У ВИМІРІ СУЧАСНИХ ВИМОГ І РЕАЛЙ}

взаємодії з ним тощо. Як бачимо, у людини соціономічної професії практично відсугні “готові рецепти" професійної діяльності, оскільки незалежно від сфери ії праці, вона завжди має справу 3 іншою людиною, кожна 3 яких відзначається своїм ціннісним світом, особливими реакціями на оточующе середовище, обставини і власні проблеми, умовами існування й т.ін. Відповідно, для фахівця важливо не тільки володіти певною сумою знань, умінь і навичок, яких він набуває під час навчання у вищій школі, але й систематично займатися самоосвітою, самоудосконаленням, щоби підвищувати свій професіоналізм, розвивати власний творчий потенціал. У даному контексті доцільно відзначити й те, що соціономічні професії, об’єктом праці яких є інші люди, передбачають постійну й безпосередню 3 ними взаємодію та спілкування упроцесі професійної діяльності (яке, безумовно, повинно бути конструктивним та безконфліктним), надзвичайно тісно пов'язані 3 підвищеною моральною відповідальністю цих фахівців, зрілістю їх професійної самосвідомості [7].

Розглядаючи психологічні засади майбутньої професійної діяльності спеціалістів соціономічного профіля, науковець В. Ісаєв наголошує на високих психологічних, професійних та особистісних вимогах до представників даної професії, зауважуючи при цьому, що водночас самі соціономічні професії характеризуються відсутністю єдиних і жорстких вимог як до процесу професійної діяльності, так і до продукту праці $[5,204]$.

3 огляду на представлену узагальнену характеристику допомагаючих професій постає необхідність постійного удосконалення професійної підготовки майбутніх фахівців соціономічної сфери, здатних добре орієнтуватися у сучасних реаліях, адекватно відповідати на виклики сьогодення відповідно до потреб суспільства в різних галузях діяльності (часто діяти й на випередження), готових до змін і розвитку, прийняття самостійних рішень не тільки у типових, а й у складних ситуаціях, співвіднесення своїх життєвих сенсів із пріоритетами суспільства та загальнолюдськими цінностями.

Підготовка висококваліфікованих професіоналів була і залишається найважливішою задачею вищої школи. Молода людина за час навчання повинна набути такої сукупності компетентностей, завдяки яким вона може бути конкурентноспроможною на ринку праці не тільки сьогодні, але й через роки 3 огляду на стрімкий розвиток науково-технічного прогресу, суспільства, що часто супроводжується не тільки позитивом, але й непередбачуваними загрозами. А, отже, виникає цілком логічне питання: до чого ми повинні готувати майбутніх фахівців соціономічної сфери в сучасних соціально-економічних умовах і що доцільно змінити, удосконалити в моделях, змісті, структурі, формах і методах професійної підготовки студентів?

Перехід України до нової освітньої парадигми, у якій особливої актуальності набули гуманістичний і компетентнісний підходи, зумовив зміни у стратегії професійної підготовки майбугніх фахівців соціономічної сфери у вищій школі, багатоплановість діяльності яких вимагає виконання широкого спектру професійних ролей $і$ функцій.

У практиці організації навчального процесу у вищій школі знайшли втілення різні моделі навчання: пасивна, в межах якої домінуючою в організації навчального процесу залишається одностороння форма комунікації як способу передачі інформації викладачем 3 наступним іiі відтворенням студентом; а також активна та інтеративна, що переводять процес навчання у нову площину суб' єкт-суб' єктних відносин між викладачем і студентом.

Як відзначає науковець Н. Гордієнко, зміна вектора мети освіти, орієнтація не на знаннєвий, а на компетентнісний підхід у професійній підготовці майбутніх фахівців соціономічної сфери вимагає не озброєння студента сумою нормативних знань, а насамперед формування здатності розв'язувати проблеми, що виникають упізнавальній, технологічній і психічній діяльності, у сферах етичних, соціальних, правових, професійних, особистих відносин [4, 37]. Таким чином, зорієнтованість компетентнісної освіти на практичні результати, а не на фундаментальність і обсяг здобутих знань (акцент із щзо вивчати переноситься на те, як навчати) зумовлює перебудову організації всього освітнього процесу, що насамперед вимагає докорінної зміни як педагогічної позиції викладача, так і студента [1, 11 - 14], актуалізує впровадження активної та інтерактивної моделей навчання у вищій школі 3 метою формування й розвитку у майбутніх фахівців системи здатностей діяти практично, творчо застосовувати набуті знання і досвід у різних ситуаціях.

При цьому надзавданням професійної підготовки в рамках компетентнісного підходу стає надбання студентом досвіду самостійного аналізу і діяльності в конкретних ситуаціях, що вимагає від нього відповідних здібностей. 


\section{ПРОФЕСІЙНАПІДГОТОВКАФАХІВЦІВСОЦІОНОМІЧНИХ ПРОФЕСІЙ У ВИМІРІ СУЧАСНИХ ВИМОГ І РЕАЛІЙ}

3 огляду на те, що у вітчизняній вищій освіті усе ще переважає теоретична складова, реалізація даного надзавдання, на наше переконання, можлива за умови впровадження насамперед інтерактивної моделі навчання, організації самостійної пізнавальної діяльності студентів у штучно створеному викладачем професійному середовищі. Це може бути аналіз конкретних ситуацій, робота 3 кейсами, ділові рольові ігри, що дає можливість поєднати теоретичнупідготовку з формуванням практичних умінь і навичок, необхідних для творчої діяльності у реальній професійній сфері, виступає вагомим підгрунтям для розвитку метакомпетентності майбутніх фахівців, їх здатності до рефлексії та відповідальності за прийняті рішення, здібностей децентрації, розвитку аналітичних і комунікативних умінь і навичок тощо [8].

Надання переваги інтеративній моделі професійної підготовки у вищій школі зумовлено ще й тим, що інтерактивні методи - це система способів діалогічної взаємодії, спрямованої на усвідомлення діалогу, що набуває особливої актуальності для фахівців соціономічних професій, для яких комунікативна функція виступає однією 3 провідних. Комунікативна взаємодія пронизує всі види їх професійної діяльності, тому від рівня сформованості комунікативної компетенції значною мірою залежить успіх усього процесу надання допомоги. Доцільно зауважити й те, що саме комунікативна діяльність виступає одним із суттєвих проявів креативності фахівця, що проявляється, наприклад, у пошуці змісту і способів передачі інформації, у творчості взаємодії, здатності зацікавити, захопити свого співрозмовника, підтримувати з ним контакт, в умінні правильно зорієнтуватися у нестандартних професійних ситуаціях й т.ін. Комунікативна компетенція, за висновками Д. Годлевської, виступає одночасно і складовою, і базовою характеристикою професійної компетенції фахівця соціономічної сфери, що регулює всю систему ставлень людини до природного і соціального світу, а також до самої себе як синтезу цих двох світів [3].

Формуванню професійної компетентності сприяє використання під час практичних занять ділових рольових ігор - методу, суть якого полягає у “програванні ролей”, імпровізованому розігруванні заданої ситуації, яка містить певну професійну проблему, з метою максимального залучення учасників до розв'язання цієї проблеми. Таким чином, гра у штучно створеному професійному середовищі стає тією основою, що готує майбутніх фахівців до неігрової, реальної серйозної ситуації. 3 огляду на це під час проведення таких занять важливо, щоби ролі і функції гравців адекватно відбивали “посадову картину” того фрагменту професійної діяльності, що моделюється у грі, а правила гри відображали характеристики реальних процесів і явищ, що мають місце у прототипах дійсності, яка моделюється. За цих умов учасники гри імпровізованої професійної ситуації - стають конкретними носіями виробничих відносин, які складаються у колективі [4]. Сам же процес участі студентів у діловій грі, що $є$ відтворенням контексту майбутнього фаху у його предметному і соціальному аспектах, дозволяє їм опановувати норми професійних та соціальних дій, принципи безконфліктної комунікативної взаємодії, дає можливість не боятися робити помилки, удосконалювати практичні уміння й навички, активізовувати власний творчий потенціал, адже у більшості випадків при розв'язанні запропонованих ситуацій не існує єдиного правильного рішення, що вимагає доведення та обгрунтування учасниками власної точки зору на професійну поведінку у цій ситуації. Одночасне існування декількох альтернативних рішень і можливість вибору сприяє формуванню у студентів певної гнучкості підходу до розгляду професійних проблем.

Доцільно відзначити й те, що уділовій рольовій грі реалізуються колективна форма навчальної діяльності (яка сприяє формуванню навичок командної роботи, партнерства, співпраці, співтворчості), а також моделі діалектики професійної діяльності.

Важливим аргументом на користь застосування у навчальній діяльності інтерактивних методів, зокрема рольових ігор, може слугувати й те, що вони можуть служити як засобом актуалізації, застосування і закріплення знань, так і засобом розвитку комунікативної компетенції, що досягається за рахунок взаємодії учасників гри.

Розгляд професійної підготовки фахівців соціономічних професій у вимірі сучасних вимог та реалій вимагає окреслення ще одного надзвичайно важливого аспекту, зумовленого тенденціми інтеграції і глобалізації у сучасному світі, необхідністю гармонізації архітектури європейського освітнього простору, до якого приєдналася і Україна, участю українських фахівців у міжнародних проектах. Це, насамперед, вивчення студентами іноземної мови професійного спрямування, що спрятиме не тільки розширенню світогляду майбутніх фахівців, а й дозволить знайомитись 3 передовим зарубіжним досвідом у своій галузі, з новими технологіями, відкриттями 
та тенденціями в розвитку науки і техніки, налагоджувати контакти із зарубіжними партнерами, інвесторами тощо. А, отже, іноземне спілкування в сучасних умовах стає суттєвим компонентом професійної діяльності фахівців соціономічної сфери.

Висновки і перспективи подальших досліджень. Здійснений нами аналіз окремих особливостей професійної підготовки фахівців соціономічних професій у світлі сучасних вимог та реалій дозволив дійти висновку, що конкурентоспроможність молодого спеціаліста виступає, з одного боку, фактором розвитку його професійної компетентності та особистісних якостей в інтересах сучасного суспільства, а 3 іншого-показником якості професійної підготовки студентів у вищій школі.

Компетентність сучасного фахівця соціономічної сфери передбачає постійне оновлення знання, удосконалення умінь і навичок для успішного вирішення професійних завдань, чітку орієнтацію на майбутнє, а, оскільки знання неможливо дати на декілька років вперед, сьогодення вимагає навчити студентів вчитися і перенавчатися, де головним критерієм навченості можна вважати готовність до самостійної діяльності на кожному етапі професійного становлення. При цьому вища школа має створити такі умови, які б спонукали студентів до самостійного пошуку, саморозвитку, самовдосконалення, індивідуальної творчої роботи, адже фахівець, який працює у системі “людина - людина”, повинен уміти поглиблювати знання і вдосконалювати свій професіоналізм протягом усього трудового життя.

Перспективу подальших наукових розвідок вбачаємо у дослідженні технологій кооперативного та колаборативного навчання упроцесі професійної підготовки майбутніх фахівців соціономічної сфери.

\section{ЛІТЕРАТУРА}

1. Активізація навчального процесу у сучасній вищій школі: Метод. огляд / Уклад. Л.А. Якимова. - К.: ДП “Вид. дім “Персонал”, 2010. - 32 с.

2. Болучевская В.В. Профессиональное самоопределение будущих специалистов помогающих профессий. Монография. Волгоград: Изд-во ВолГМУ, 2010. - 264 с.

3. Годлевська Д.М. Формування професійної комунікативної компетентності майбутніх соціальних працівників в умовах педагогічного університету: Автореф. дис. канд. пед. наук: спец. 13.00.05 - соціальна педагогіка/ Національний педагогічний університет імені М.П. Драгоманова. - K., 2007. - 25 c.
4. Гордієнко Н.В. До проблеми формування професійної компетентності майбутніх соціальних педагогів у ВНЗ / Н.В.Гордієнко // Наукові записки. Серія "Психолого-педагогічні науки" (Ніжинський державний університет імні Миколи Гоголя) $\backslash$ за заг. ред. проф. Є.І.Коваленко. - Ніжин: НДУ ім. М.Гоголя, 2014. - №1. - 273 с. - С.35 40.

5. Исаев В.П. Психологические особенности будущей профессиональной деятельности специалистов социономического профиля / В.П.Исаев // МНКО. Мир науки, культуры, образования. 2013. - № 4(41). - С. 203-206.

6. Каверина Р.Д. Мир профессий - М.: Молодая гвардия, 1986, - 300с.

7. Климов Е.А. Психология профессионального самоопределения: Учеб. пособие для студ. высш. пед. учеб. заведений / Евгений Александрович Климов. - М.: Издательский центр “Академия”, 2005. -304 c.

8. Сурмін Ю.П. Метод аналізу ситуацій (Case study) та його навчальні можливості. Глобалізація і Болонський процес: проблеми і технології: монографія / Ю.П. Сурмін. - К. : МАУП, 2005.

\section{REFERENCES}

1. Yakymova, L. A. (2010). Aktyvizatsiia navchalnoho protsesu u suchasnii vyshchii shkoli: Metod. ohliad [The activation of the educational process in the modern High School: Method. Review]. Kyiv: DP "Vyd. dim "Personal", 32 p. [in Ukrainian].

2. Boluchevskaya, V.V. (2010). Professionalnoe samoopredelenie budushchikh spetsialistov pomogayushchikh professiy [The professional selfdetermination of the future professionals of assisting professions]. Volgograd: Izd-vo VolGMU, 264 p. [in Russian].

3. Hodlevska, D. M. (2007). Formuvannia profesiinoi komunikatyvnoi kompetentnosti maibutnikh sotsialnykh pratsivnykiv v umovakh pedahohichnoho universytetu [The formation of professional communicative competence of future social workers in the conditions of a Pedagogical University]. Extended abstract of candidate's thesis. National Mukhaylo Drahomanov Pedagogical University. Kyiv, 25 p. [in Ukrainian].

4. Hordiienko, N.V. (2014). Do problemy formuvannia profesiinoi kompetentnosti maibutnikh sotsialnykh pedahohiv u VNZ [Concerning thre problem of formation of professional competence of future social educators of higher educational institutions]. Proceedings. Series: "Psychological and pedagogical Sciences" (Nizhyn Mykola Hohol State University). (Ed.).Ye.I. Kovalenko. 
Nizhyn: NDU im. M.Hoholia, no.1, 273 p; pp.35 40. [in Ukrainian].

5. Isaev, V.P. (2013). Psikhologicheskie osobennosti budushchey professionalnoy deyatelnosti spetsialistov sotsionomicheskogo profilya [The psychological peculiarities of the future professional activity of specialists of sociological profile]. The world of science, culture, and education,no.4(41), pp. 203-206. [in Russian].

6. Kaverina, R.D. (1986). Mir professiy [The world of professions]. Moscov: Molodaya gvardiya, 300 p. [in Russian].

7. Klimov, Ye.A. (2005). Psikhologiya professionalnogo samoopredeleniya: Ucheb. posobie dlya stud. vyssh. ped. ucheb. Zavedeniy [Psychology of professional self-determination: educational manual for the students of higher educational pedagogical establishments]. Moscov: Izdatelskiy tsentr "Akademiya", 304 p. [in Russian].

8. Surmin, Yu. P. (2005). Metod analizu sytuatsii (Case study) ta yoho navchalni mozhlyvosti. Hlobalizatsiia $i$ Bolonskyi protses: problemy $i$ tekhnolohii [The method of Analysis the situations (Case Study) and its educational capabilities. Globalization and the Bologna Process: Problems and Technologies]. Kyiv: MAUP. [in Ukrainian].

Стаття надійшла до редакції 04.09.2018

УДК $811.27 ’ 38^{\prime} 246.2$

DOI:

Анна Огар, кандидат філологічних наук, старший викладач кафедри філологічних дисциплін та методики їх викладання у початковій школі Дрогобицького державного педагогічного університету імені Івана Франка

\section{КОНЦЕПТОСФЕРА ДИТЯЧИХ ПЕРІОДИЧНИХ ВИДАНЬ}

У статті йдеться про дискурс дитячих періодичних видань як сукупність апеляції до концептів, зумовлений вибором мовних засобів відповідно до інтенцій мовия. 3 'ясовано, щзо на сторінках журналів актуалізовано передусім біологічні та предметні концепти, рідше - ландшафтні. 3-поміж соиіальних концептів частотно виділено концепти країн, національностей, занять. Особливу увагу приділено вербалізаціі концепту Украӥна. До ключових концептів дитячих періодичних видань належать також моральні (етичні) та духовні конщепти.

Ключові слова: концепт; концептосфера; дискурс; вербалізація; класифікація концептів.

Лim. 7.

Anna Ogar, Ph.D.(Philology), Senior Lecturer of the Philological Disciplines and Methods of Teaching at the Elementary School Department Drohobych Ivan Franko State Pedagogical University

\section{THE CONCEPTOSPHERE OF PERIODICALS FOR CHILDREN}

The article deals with the discourse of the children's periodicals as a set of appeal to concepts, due to the choice of linguistic means in accordance with the intentions of the speaker. It was found out that on the pages of magazines the biological and subject concepts, and at least the landscape ones, were actualized in the first place. Among the social concepts, the concepts of countries, nationalities, occupations are often highlighted. Particular attention is paid to the verbalization of the concept of Ukraine. The key concepts of the children's periodicals include the moral (ethical) and spiritual concepts.

A thorough analysis of the children's periodicals testifies the usage of paralinguistic means: a syngraphic (stylistically justified variation of punctuation marks), a supragrapheme (variation of the font), a topography (deviation from the standard design of the text array that allocates it, accents it), architectonics, the professional children's illustration.

The analyzed magazines develop the children speech, logical thinking, observation, arbitrary attention, memory. They include children into the system of social relations; allow them to gain social experience, to model their behavior. And yet - they are attracted to the national heritage, to the achievements of their people.

Keywords: a concept; concept sphere; discourse; verbalization; classification of concepts.

П остановка проблеми. Мова унікальне джерело інформації про соціально-культурну реальність. Будь-яка динаміка в навкіллі провокує процес осмислення, конструювання нового смислу, тобто концептуалізацію, а отже - зміни в мові, найдоступнішій формі відображення знань про світ і найважливішому інструменті, через який людина ці знання отримує. Отож вивчення мови - це не лише засвоєння мовних форм і явищ, це осягнення 